\title{
SpringerBriefs in Fire
}

\author{
Series editor
}

James A. Milke, College Park, USA 
More information about this series at http://www.springer.com/series/10476 
Rosalie Wills - James A. Milke

Sara Royle · Kristin Steranka

Best Practices for

Commercial Roof-Mounted

Photovoltaic System

Installation

第 Springer 
Rosalie Wills

Department of Fire Protection Engineering

University of Maryland

College Park, MD

USA

James A. Milke

Department of Fire Protection Engineering

University of Maryland

College Park, MD

USA
Sara Royle

Department of Fire Protection Engineering

University of Maryland

College Park, MD

USA

Kristin Steranka

Department of Fire Protection Engineering

University of Maryland

College Park, MD

USA
ISSN 2193-6595

SpringerBriefs in Fire

ISBN 978-1-4939-2882-8

DOI 10.1007/978-1-4939-2883-5
ISSN 2193-6609 (electronic)

ISBN 978-1-4939-2883-5 (eBook)

Library of Congress Control Number: 2015940973

Springer New York Heidelberg Dordrecht London

(c) Fire Protection Research Foundation 2015

This work is subject to copyright. All rights are reserved by the Publisher, whether the whole or part of the material is concerned, specifically the rights of translation, reprinting, reuse of illustrations, recitation, broadcasting, reproduction on microfilms or in any other physical way, and transmission or information storage and retrieval, electronic adaptation, computer software, or by similar or dissimilar methodology now known or hereafter developed.

The use of general descriptive names, registered names, trademarks, service marks, etc. in this publication does not imply, even in the absence of a specific statement, that such names are exempt from the relevant protective laws and regulations and therefore free for general use.

The publisher, the authors and the editors are safe to assume that the advice and information in this book are believed to be true and accurate at the date of publication. Neither the publisher nor the authors or the editors give a warranty, express or implied, with respect to the material contained herein or for any errors or omissions that may have been made.

Printed on acid-free paper

Springer Science+Business Media LLC New York is part of Springer Science+Business Media (www.springer.com) 


\section{Preface}

Although PV systems provide many benefits to the environment, there are hazards associated with them being installed onto rooftops. The installation of PV systems on roofs creates electrical, fire, structural, and weather-related hazards that are not adequately addressed by current codes, standards, and guidance documents. Significant progress has been made in the past years (as will be identified in this report), but there are still gaps that need to be addressed.

The purpose of this book is to compile information on a wide variety of hazards and damage potential created by the installation of photovoltaic (PV) systems on commercial roof structures.

The book reviews recent major PV fire incidents including those at Bakersfield, CA, and Mount Holly, NC, Goch, Germany, DeLanco, NJ and LaFarge, WI, and concludes that much can be learned from these and other non-fire-related failure incidents, most of which are not documented in the public literature.

The book then summarizes basic performance categories associated with PV panel installation practice and identifies key installation features impacting this performance. These include performance under structural loading, wind loads, hail, snow, debris accumulation, seismic loads, and fire hazards including flammability of components, ignition hazards, and electrical hazards associated with fire fighter operations.

The book reviews existing information in the literature related to the best practices for installation to address the performance issues described above. A comprehensive reference section is provided.

Finally, an assessment of key gaps in available information and understanding of performance is presented, highlighting areas of additional needed work. These include:

- Long-term performance of PV modules

- Design for wind in the presence of deflectors and shrouds

- Long-term performance with respect to hail damage

- Design for accumulated snow load 


\section{Acknowledgments}

Appreciation is extended to the Fire Protection Research Foundation for support to this project. Special appreciation is extended to Kathleen Almand and Casey Grant for their assistance in identifying resources and providing comments on the direction of research. The comments and input from the Project Technical Panel helped to direct the study and improve the final report. 


\section{Project Technical Panel}

Larry Sherwood, Solar America Board for Codes and Standards

Remington Brown, Insurance Institute for Business and Home Safety

Bill Brooks, Solar Energy Industries Association

Tom Smith, TL Smith Consulting, Inc.

Barbara Mentzer, City of Hartford

Daniel Joyeux, Efectis (FR)

Michael Bertels, Dutch Fire Department 


\section{Project Sponsors}

CNA Insurance

FM Global

Liberty Mutual

Tokio Marine

Travelers Insurance

XL Gaps

Zurich NA 


\section{Contents}

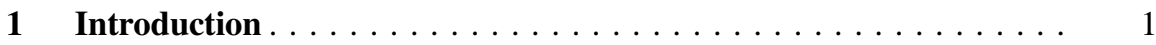

1.1 Research Objective . . . . . . . . . . . . . . . 1

1.2 Background ....................... 1

1.3 Overview of Previous Incidents . . . . . . . . . . . 2

1.4 Overview of Photovoltaic (PV) Systems $\ldots \ldots \ldots \ldots \ldots \ldots 6$

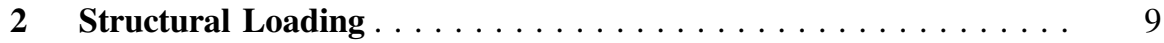

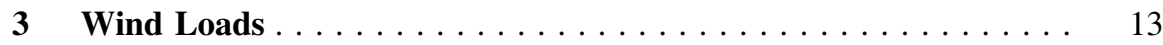

4 Hail . . . . . . . . . . . . . . . . . . . . . 23

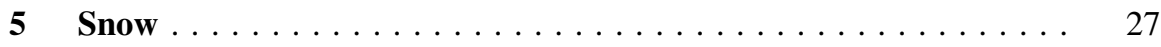

6 Debris Accumulation. . . . . . . . . . . . . . . . . 29

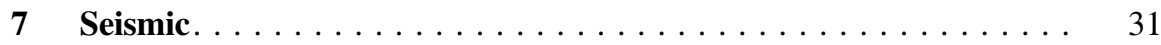

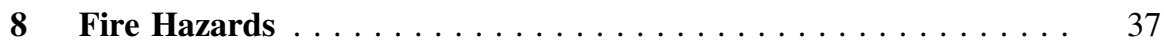

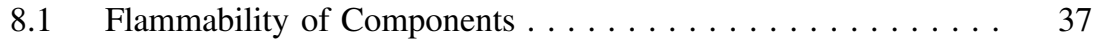

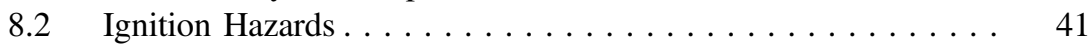

9 Electrical Hazards Associated with Fire Fighting Operations . . . 47

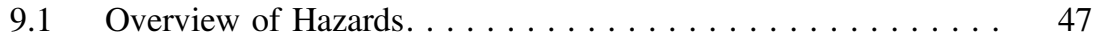

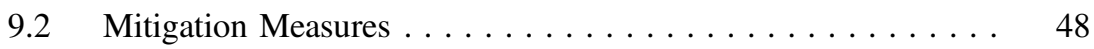

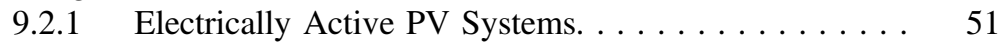

9.2.2 Suppression Tactics. . . . . . . . . . . . . 54

9.2 .3 Ventilation Tactics . . . . . . . . . . . 55 
10 Weather-Related Maintenance Considerations . . . . . . . . . . . 57

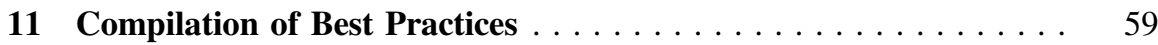

11.1 Structural Loading . . . . . . . . . . . . . . . . . . . 59

11.2 Wind Loads . . . . . . . . . . . . . . . . . . 59

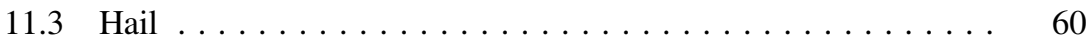

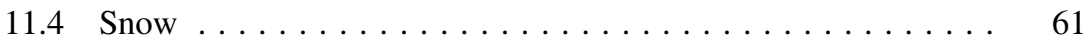

11.5 Debris Accumulation. ................... 61

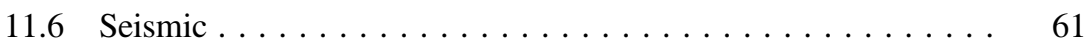

11.7 Fire Hazards. . . . . . . . . . . . . . . . . 62

11.7.1 Flammability of Components ............ 62

11.7.2 Ignition Hazards . . . . . . . . . . . . . . . 63

11.8 Electrical Hazards Associated with Fire Fighting Operations. . . 65

11.9 Weather-Related Maintenance Considerations . . . . . . . . . . 67

12 Hazard Gap Analysis . . . . . . . . . . . . . . . . . . . 69

12.1 General Knowledge Gaps. . . . . . . . . . . . . . . . . . . . . 69

12.2 Testing and Calculation Gaps . . . . . . . . . . . . 70

12.3 Structural and Wind Loads. . . . . . . . . . . . . . . . 70

12.4 Hail Impact Forces . . . . . . . . . . . . . . . . . . . . 70

12.5 Snow Loads. . . . . . . . . . . . . . . . . . . . . . 71

12.6 Seismic Hazards . . . . . . . . . . . . . . . . . . 71

12.7 Fire Hazards. . . . . . . . . . . . . . . . 71

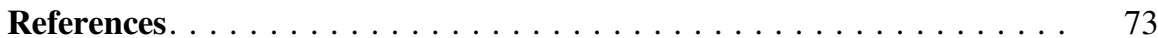

